\section{Orofacial clefts in the newborn and environmental and occupational parental exposures: a case-control study in Rio de Janeiro, Brazil}

\section{Fendas orofaciais no recém-nascido e exposições ambientais e ocupacionais dos pais: um estudo caso-controle no Rio de Janeiro, Brasil}

Isabel Cristina G Leite 1

Francisco José Roma Paumgartten 2

Sérgio Koifman 3

1 Universidade Presidente Antônio Carlos. Campus de Juiz de Fora. Avenida Juiz de Fora, 1100. Granjas Betânia. Juiz de Fora, MG, Brasil. CEP 36.048-000.

2 Laboratório de Toxicologia Ambiental. Fundação Oswaldo Cruz. Manguinhos, Rio de Janeiro, RJ, Brasil.

3 Departamento de Epidemiologia e Métodos Quantitativos em Saúde. Escola Nacional de Saúde Pública. Fundação Oswaldo Cruz. Rio de Janeiro, RJ, Brasil.

\begin{abstract}
Objectives: to evaluate risk factors involving environmental and occupational parental exposures associated with occurrence of orofacial clefts in a group of Brazilian children.

Methods: a secondary base case-control study was conducted with 274 cases of cleft lip with or without cleft palate $(C L \pm P)$ and cleft palate only, with 548 controls (1:2). The authors analyzed residential proximity to industrial areas, exposure to commercial insecticides, agricultural pesticides, and vector control spraying, as well as various occupational exposures. The results were obtained by conditional regression analysis.

Results: proximity to industrial installations as a risk factor (OR =3,32; 95\% CI: 2,18-5,05) for all orofacial clefts, as well as the combined use of household insecticides and urban vector control pesticide spraying $(O R=5,73 ; 95 \% C I: 2,51-11,28)$. A group of maternal occupations heavily associated with orofacial clefts was domestic services $(O R=2,89 ; 95 \% C I$ : 1,76-4,86).

Conclusions: solvents are frequently associated with $C L \pm P$ and that they are contained in numerous industrial products and household cleaning products, the results pertaining to occupational exposure become plausible. Other associations such as the routine use of domestic insecticides require further specific research for confirmation of the hypothesis.
\end{abstract}

Key words Insecticides, Pesticides, Cleft lip

\section{Resumo}

Objetivos: avaliar fatores de risco envolvendo exposições ambientais e ocupacionais dos pais associadas com a ocorrência de fendas orofaciais em um grupo de crianças brasileiras.

Métodos: estudo caso-controle de base secundária reuniu 274 casos de portadores de fendas lábio-palatinas $(F L \pm P)$ e fendas palatinas isoladas $e$ 548 controles (1:2). Foram analisadas as variáveis proximidade residencial a área industriais, exposição a inseticidas comerciais, pesticidas agrícolas, e usados no controle de vetores, bem como várias exposições ocupacionais. Os resultados foram obtidos através de análise de regressão condicional.

Resultados: a proximidade a instalações industriais como potencial fator de risco $(O R=3,32$; IC $95 \%$ : 2,18-5,05) para fendas orofaciais, bem como a combinação do uso doméstico de inseticidas e o controle urbano de vetores (OR = 5,73; IC95\%: 2,51-11,28). A ocupação profissional materna mais fortemente associada ao desfecho foram os serviços domésticos (OR = 2,89; IC95\%: 1,76-4,86).

Conclusões: admitindo os relatos da literatura de que solventes estão freqüentemente associados a FL $\pm P$ e que estes estão presentes em inúmeros produtos industriais e de uso doméstico, os resultados obtidos são plausíveis. Outras associações, como o uso rotineiro de inseticidas domésticos requerem estudos futuros para confirmação da hipótese.

Palavras-chave Inseticidas, Praguicidas, Lábio fissurado 


\section{Introduction}

The association between congenital malformations and maternal occupational exposure has been described in numerous epidemiological studies. Thus, various studies have associated central nervous system malformations with work in commerce ${ }^{1}$ and exposure to solvents, 2,3 as well as the development of different groups of malformations in children of health care professionals, ${ }^{3}$ among others. It is felt that potentially harmful exposures can affect parental germ cells before conception or embryonic somatic cells after conception. In both situations cell death can be induced, as well as cellular dysfunctions leading to congenital malformations. ${ }^{3}$ Such observations have gained greater importance as the proportion of childbearing-age women in both the formal and informal labor markets has increased progressively in various countries, including Brazil. ${ }^{4}$

Besides various exposures to potentially teratogenic substances in the workplace, studies have highlighted multiple sources of exposure to pesticides, organic and inorganic water and soil contaminants, and industrial emission of toxic gases. 5 There is growing consensus in the scientific community concerning the impact of these environmental contaminants on human reproductive health. However, few epidemiological studies have been conducted to measure the consequences, for example, of a potential increase in the distribution of congenital malformations in the offspring of individuals exposed to specific teratogenic agents. The two main difficulties are the measurement of these multiple sources and the use of prevalent malformations for outcome analysis, which can be interpreted as resulting from the effect of survival within a cohort of malformed offspring. 6

In the case of typical orofacial clefts - cleft lip with or without cleft palate plus cleft palate only, $[(\mathrm{CL} \pm \mathrm{P})+\mathrm{CPO})]-$ few studies have been conducted specifically to evaluate the associations between occupational and environmental exposures and this group of malformations. Environmental toxic factors are believed to account for $60 \%$ of the etiology of such clefts, besides displaying interaction with genes participating in morphogenesis, like TGF $\alpha / T G F \beta$, RARA, BCL3, and MSX1.7

This article presents the results of a case-control study designed to determine the magnitude of the association between maternal and paternal exposure to specific environmental agents and the development of $[(\mathrm{CL} \pm \mathrm{P})+\mathrm{CPO}]$ in children under 24 months of age treated at several public hospitals in the State of Rio de Janeiro.

\section{Methods}

A secondary-base case-control study was conducted in a public referral hospital for cranio-facial malformations, located in the city of Rio de Janeiro, RJ, Brazil. In addition to the interdisciplinary treatment for these specific patients, this hospital provides various other types of pediatric care. This study's methodology has been described elsewhere. ${ }^{8}$ Cases of orofacial clefts were selected at random among children 0 to 24 months of age, and hospital controls were matched by sex, age ( \pm 2 months), and area of residence. Controls were selected among children who had been hospitalized for at least seven days. The principal diseases in the controls included complications of viral infections like varicella; meningitis and encephalitis; orthopedic disorders; burns. Proven or suspected cases of syndromic malformations were excluded from controls, thus resulting in a study consisting of 274 cases and 548 controls. Standardized interviews were conducted with the parents or caregivers of cases and controls to collect information on potential confounding factors between $[(\mathrm{CL} \pm \mathrm{P})+\mathrm{CPO}]$ and exposure to chemical agents, including socioeconomic data, maternal reproductive and medical history (systemic diseases and use of medication), life habits (alcohol consumption, smoking, and use of illicit drugs), and evolution of the index gestation. Variables related to household and occupational exposure were recorded based on the report of the parent or caregiver (in most cases the mother), who also served as surrogate informant for paternal exposures, providing the independent variables in the present study. All questions were subdivided into two periods: one year prior to the index gestation and the first trimester of pregnancy. Data were collected on maternal and paternal occupational history during this period, reported routine use of chemical products (brand name and frequency and purpose of use), industrial machinery operated by parents, and use of personal protective equipment. Specific questionnaires were also applied for housewives, farm workers (agriculture and cattle-raising), and gardening when there was a history of such activities. 9

Use of insecticides in the domestic environment was investigated, gathering data on the brand names used, purpose and frequency of use, and periodicity of visits by Ministry of Health agents working in vector control programs responsible for spraying chemical agents in the domestic environment.

The presence of factories and other industrial installations in the area of residence was also recorded when they were reported to be located within three 
blocks of the residence and/or perceived by the interviewee as emitting industrial waste into the environment (soil, water, or air) or producing noise, trepidation, or other occurrences directly associated with the presence of such installations in the vicinity.

Coding of maternal and paternal occupations was obtained from the International Standard Classification of Occupations. 10 Measurements of association were determined for the professional category of teachers, professionals, and related professions (subdivided into health and others); students; administrative workers; clergy; sales (commerce); domestic services (subdivided into beauty services and domestic services proper); agricultural sector; and industrial work (subdivided into manufacturing and others).

This study was approved by all the respective institutional and governmental ethics committees and agencies based on Ruling n. ${ }^{\circ} 196 / 96$ of the Brazilian National Health Council.

Risk measurements (odds ratios: OR) and their respective $95 \%$ confidence intervals $(95 \% \mathrm{CI})$ were calculated in the conditional logistic regression analysis using the Egret program (Statistical and Epidemiology Research Corporation, 1995). The stratified Mantel-Haentzel analysis was conducted in some situations to evaluate the risk tendency, and separate analyses were conducted for cleft lip with or without cleft palate $(\mathrm{CL} \pm \mathrm{P})$ and cleft palate only (CPO). The univariate and bivariate analyses evaluated the possibility of confounding when the OR by stratum presented a variation greater than $20 \%$ in relation to the crude OR, as well as interaction, using Wolff's chi-square. The regression analyses controlled for the variables maternal age, since the literature reports an increase in the probability of congenital malformations associated with increased age, and maternal schooling, which did not show significant differences between cases and controls in most strata but did present a difference for secondary schooling, which includes some cases of training for middlelevel health care professionals. Some authors have suggested that health care occupations show increased risk of orofacial clefts. The ORs were also adjusted for contamination routes other than that whose effect was being investigated. The modeling criterion adopted was that of biological plausibility, using the enter method. ${ }^{11}$

\section{Results}

\section{Overall characteristics of the study population}

The overall characteristics of the study population have been described in a previous article. ${ }^{8}$ No significant differences were identified in mean maternal and paternal age between cases and controls ( 25 and 28 years, respectively), or weight and length at birth in the two groups (overall means of 3112 grams and 49 centimeters, respectively). However, stratification by gestational age (according to the Capurro method) showed differences in weight and length. There was a statistically significant association between this group of malformations and family history of orofacial clefts both for the paternal family $(\mathrm{OR}=14,01$; 95\%CI: 6,32-32,01) and maternal family $(\mathrm{OR}=5,96 ; 95 \% \mathrm{CI}: 3,03-11,84)$, as was reported kinship between the two parents in the case of cleft lip with or without cleft palate $(\mathrm{OR}=3,80 ; 95 \% \mathrm{CI}$ : 1,27-12,18).

Reported history of maternal systemic disease was associated with $[(\mathrm{CL} \pm \mathrm{CP})+\mathrm{CPO}]$ in the case of malformations ( $\mathrm{OR}=8,01 ; 95 \% \mathrm{CI}: 2,23-28,81)$, gynecological infections $(\mathrm{OR}=2,77 ; 95 \% \mathrm{CI}: 1,50$ $5,10)$, dysrhythmia/seizures $(\mathrm{OR}=7,11 ; 95 \% \mathrm{CI}$ : $2,57-19,7)$, and viral infections $(\mathrm{OR}=7,57$; 95\% CI: 2,46-23,32). Although the associations were not statistically significant, there were reports of prior stillbirths $(\mathrm{OR}=2,22$; 95\% CI: 0,88-5,65) and spontaneous abortions $(\mathrm{OR}=1,42 ; 95 \% \mathrm{CI}$ : 0,95-2,13) among the total cases analyzed.

\section{Environmental and occupational exposures and} the occurrence of orofacial clefts

Reported presence of factories or industrial installations close to the place of residence both during the year prior to the index gestation and during the first trimester of pregnancy generated a statistically significant risk measure for all groups of malformations analyzed $[(\mathrm{CL} \pm \mathrm{P})+\mathrm{CPO}]($ Table 1$)$. The types of industrial activity most frequently described were steelmaking, metallurgy, and petroleum refining and petroleum product manufacturing. 
Table 1

Adjusted odds ratio for the association between $[(C L \pm C P)+C P O]$ and residential proximity to factories.

\begin{tabular}{|c|c|c|c|c|c|c|}
\hline $\begin{array}{l}\text { Presence of factories in the } \\
\text { vicinity }\end{array}$ & $\frac{\text { Controls }}{\mathrm{n}}$ & $\frac{\mathrm{CL} \pm \mathrm{P}}{\mathrm{n}}$ & $\frac{\mathrm{CPO}}{\mathrm{n}}$ & $\begin{array}{c}\mathrm{CL} \pm \mathrm{CP} \\
\text { OR a } \\
(95 \% \mathrm{Cl})\end{array}$ & $\begin{array}{c}\text { CPO } \\
\text { OR a } \\
(95 \% \mathrm{Cl})\end{array}$ & $\begin{array}{c}(C L \pm C P)+C P O] \\
\text { OR a } \\
(C 195 \%)\end{array}$ \\
\hline Non-existent & 501 & 160 & 51 & 1,00 & 1,00 & 1,00 \\
\hline 1st trimester & 47 & 48 & 15 & $\begin{array}{c}3,27 \\
(2,03-5,28)\end{array}$ & $\begin{array}{c}3,25 \\
(1,32-8,05)\end{array}$ & $\begin{array}{c}3,32 \\
(2,18-5,05)\end{array}$ \\
\hline
\end{tabular}

$\mathrm{CL} \pm \mathrm{CP}=$ Cleft lip with or without cleft palate; $\mathrm{CPO}=$ Cleft palate only; $[(\mathrm{CL} \pm \mathrm{P})+\mathrm{CPO}]=$ All cases of nonsyndromic orofacial clefts;

$\mathrm{n}$, excludes indeterminate responses; a Adjusted for schooling, maternal age, and exposure to toxic agents in agriculture

The associations were also analyzed between $[(\mathrm{CL} \pm \mathrm{P})+\mathrm{CPO}]$ and routine domestic use of insecticides or frequent visits for spraying by Ministry of Health vector control agents in the vicinity. The data are shown in Table 2. Note that domestic use of insecticides combined with a history of vector control in the vicinity showed significant risk estimates, generating an upward risk gradient for the year prior to the index gestation and the first trimester of pregnancy. No interaction was found between the two exposures (domestic insecticides/Ministry of Health spraying), regardless of the group or period analyzed.

Paid activities of the mothers of these children are described in Table 3. The study analyzes the paid work activities during the pre-gestational period, since only some $5 \%$ of all the mothers stopped working during the first trimester of pregnancy $(5,6 \%$ for $\mathrm{CL} \pm \mathrm{P}$ and $4 \%$ for $\mathrm{CPO})$. We call attention to the group including teachers, professionals, and related occupations (OR $=3,40 ; 95 \% \mathrm{CI}: 1,05-15,29)$ in the case of $\mathrm{CL} \pm \mathrm{P}$. When subdivided into the two main categories (health care sector and others, the latter including mainly teachers, educators, and sociologists), the highest risk was associated with health sector professionals (nurses, physicians, nutritionists, health technicians), although the estimates were not statistically significant. The main occupational areas identified were nursing aides and laboratory technicians. A similar pattern was observed in the group classified as domestic services, but for all orofacial clefts and $\mathrm{CL} \pm \mathrm{CP}$. When broken down by principal sub-groups, the occupations included under domestic services (domestics, janitors, baby-sitters, etc,) remained a statistically significant risk factor, Note that this sub-group does not include housewives (reference category), but only occupations involving these activities in the form of paid work. 
Adjusted odds ratio and $95 \%$ confidence interval for the association of exposure to environmental toxic agents and orofacial clefts.

\begin{tabular}{|c|c|c|c|c|c|c|}
\hline & $\frac{\text { Controls }}{\mathrm{n}}$ & $\frac{\mathrm{CL} \pm \mathrm{P}}{\mathrm{n}}$ & $\begin{array}{c}\mathrm{CPO} \\
\mathrm{n}\end{array}$ & $\begin{array}{c}\mathrm{CL} \pm \mathrm{P} \\
\text { OR a } \\
(95 \% \mathrm{Cl}) \\
\end{array}$ & $\begin{array}{c}\text { CPO } \\
\text { OR a } \\
(95 \% \mathrm{Cl}) \\
\end{array}$ & $\begin{array}{c}(C L \pm P)+C P O] \\
\text { OR a } \\
(95 \% \mathrm{Cl}) \\
\end{array}$ \\
\hline \multicolumn{7}{|l|}{$\begin{array}{l}\text { History of insecticide spraying } \\
\text { in workplace or household }\end{array}$} \\
\hline Period prior to index gestation & 28 & 20 & 8 & $\begin{array}{c}1,16 \\
(0,64--2,08)\end{array}$ & $\begin{array}{c}1,14 \\
(0,44-2,90)\end{array}$ & $\begin{array}{c}0,78 \\
(0,68-1,91)\end{array}$ \\
\hline 1st trimester & 21 & 15 & $\begin{array}{c}6 \\
0,96\end{array}$ & $\begin{array}{c}0,86 \\
(0,49-1,86)\end{array}$ & $\begin{array}{c}0,70 \\
(0,28-2,28)\end{array}$ & $(0,48-1,04)$ \\
\hline \multicolumn{7}{|l|}{$\begin{array}{l}\text { Ministry of Health }(\mathrm{MH}) \text { pesticides } \\
\text { in area of residence }\end{array}$} \\
\hline Period prior to index gestation & 102 & 78 & 24 & $\begin{array}{c}0,11 \\
(0,04--1,25)\end{array}$ & $\begin{array}{c}0,29 \\
(0,05-1,82)\end{array}$ & $\begin{array}{c}0,15 \\
(0,06-1,26)\end{array}$ \\
\hline 1 st trimester & 94 & 71 & 23 & $\begin{array}{c}0,13 \\
(0,06-1,27)\end{array}$ & $\begin{array}{c}0,22 \\
(0,04-1,64)\end{array}$ & $\begin{array}{c}0,15 \\
(0,07-1,27)\end{array}$ \\
\hline \multicolumn{7}{|l|}{ Use of commercial insecticides } \\
\hline Period prior to index gestation & 56 & 44 & 12 & $\begin{array}{c}0,91 \\
(0,30-2,74)\end{array}$ & $\begin{array}{c}0,63 \\
(0,07-4,60)\end{array}$ & $\begin{array}{c}0,83 \\
(0,32-2,13)\end{array}$ \\
\hline $1^{\text {st }}$ trimester & 70 & 56 & 14 & $\begin{array}{c}0,70 \\
(0,22-2,16)\end{array}$ & $\begin{array}{c}0,84 \\
(0,09-8,28)\end{array}$ & $\begin{array}{c}0,72 \\
(0,27-1,95)\end{array}$ \\
\hline \multicolumn{7}{|l|}{$\begin{array}{l}\text { Combination of } \mathrm{MH} \text { pesticides }+ \\
\text { household insecticides }\end{array}$} \\
\hline Period prior to index gestation & 67 & 49 & 18 & $\begin{array}{c}3,88 \\
(1,32-13,85)\end{array}$ & - & $\begin{array}{c}5,36 \\
(1,92-18,55)\end{array}$ \\
\hline 1st trimester & 65 & 47 & 18 & $\begin{array}{c}4,87 \\
(2,07-15,57)\end{array}$ & - & $\begin{array}{c}5,73 \\
(2,51-11,28)\end{array}$ \\
\hline Crops in area of residence $b$ & 29 & 41 & 16 & $\begin{array}{c}4,58 \\
(2,62-8,28)\end{array}$ & $\begin{array}{c}4,29 \\
(1,73-10,98)\end{array}$ & $\begin{array}{c}4,73 \\
(2,96-7,85)\end{array}$ \\
\hline Use of agricultural pesticides c & 5 & 11 & 3 & $\begin{array}{c}1,02 \\
(0,27-4,00)\end{array}$ & - & $\begin{array}{c}1,50 \\
(0,44-5,41)\end{array}$ \\
\hline
\end{tabular}

$\mathrm{CL} \pm \mathrm{P}=$ Cleft lip with or without cleft palate; $\mathrm{CPO}=$ Cleft palate only; $[(\mathrm{CL} \pm \mathrm{P})+\mathrm{CPO}]=$ All cases of nonsyndromic orofacial clefts; $n$, excludes indeterminate responses; a Adjusted for schooling, maternal age, and residence in agricultural area in case of use of insecticides and exposure to pesticide spraying by Ministry of Health; OR calculated using absence of study factor as the reference; $\mathrm{b}=$ Fruits, legumes, vegetables, and others; $c=$ Reported use of agricultural pesticides in vicinity of residence 
Adjusted odds ratio and $95 \%$ confidence interval for the association between maternal occupation during pre-gestational period and orofacial clefts.

\begin{tabular}{|c|c|c|c|c|c|c|}
\hline Occupations & $\frac{\text { Controls }}{\mathrm{n}}$ & $\frac{\mathrm{CL} \pm \mathrm{P}}{\mathrm{n}}$ & $\frac{\mathrm{CPO}}{\mathrm{n}}$ & $\begin{array}{c}\mathrm{CL} \pm \mathrm{P} \\
\text { OR a } \\
(95 \% \mathrm{Cl})\end{array}$ & $\begin{array}{c}\text { CPO } \\
\text { OR a } \\
(95 \% \mathrm{Cl})\end{array}$ & $\begin{array}{c}{[(C L \pm P)+C P O]} \\
\text { OR a } \\
(95 \% \mathrm{Cl})\end{array}$ \\
\hline Housewives & 221 & 113 & 31 & 1,00 & 1,00 & 1,00 \\
\hline $\begin{array}{l}\text { Teachers, professionals, and } \\
\text { related occupations }\end{array}$ & 29 & 8 & 5 & $\begin{array}{c}3,40 \\
(1,05-15,29)\end{array}$ & $\begin{array}{c}1,17 \\
(0,17-9,92)\end{array}$ & $\begin{array}{c}2,56 \\
(0,95-7,79)\end{array}$ \\
\hline Health sector & 11 & 4 & 2 & $\begin{array}{c}4,33 \\
(0,99-27,81)\end{array}$ & - & $\begin{array}{c}1,88 \\
(0,41-14,66)\end{array}$ \\
\hline Other $b$ & 18 & 4 & 3 & $\begin{array}{c}2,00 \\
(0,23-59,16)\end{array}$ & - & $\begin{array}{c}2,17 \\
(0,67-7,78)\end{array}$ \\
\hline Administrative & 19 & 10 & 6 & $\begin{array}{c}0,62 \\
(0,21-1,73)\end{array}$ & $\begin{array}{c}1,00 \\
(0,14-8,64)\end{array}$ & $\begin{array}{c}0,69 \\
(0,28-1,70)\end{array}$ \\
\hline Sales (commerce) & 77 & 27 & 12 & $\begin{array}{c}1,33 \\
(0,71-2,50)\end{array}$ & $\begin{array}{c}1,05 \\
(0,36-3,10)\end{array}$ & $\begin{array}{c}1,25 \\
(0,73-2,14)\end{array}$ \\
\hline Domestic services & 190 & 48 & 12 & $\begin{array}{c}2,14 \\
(1,37-3,46)\end{array}$ & $\begin{array}{c}2,00 \\
(0,86-9,94)\end{array}$ & $\begin{array}{c}2,11 \\
(1,42-3,21)\end{array}$ \\
\hline Beauty services & 7 & 3 & - & $\begin{array}{c}2,00 \\
(0,27-62,85)\end{array}$ & - & $\begin{array}{c}2,00 \\
(0,15-58,99)\end{array}$ \\
\hline Domestic services proper & 183 & 45 & 12 & $\begin{array}{c}2,34 \\
(1,43-3,85)\end{array}$ & $\begin{array}{c}2,53 \\
(0,91-7,08)\end{array}$ & $\begin{array}{c}2,89 \\
(1,76-4,86)\end{array}$ \\
\hline Industry & 12 & 2 & - & $\begin{array}{c}0,83 \\
(0,09-8,28)\end{array}$ & - & $\begin{array}{c}1,03 \\
(0,33-14,53)\end{array}$ \\
\hline Manufacturing & 4 & - & - & - & - & $\begin{array}{c}4,67 \\
(0,62-109,02)\end{array}$ \\
\hline Other $\mathrm{c}$ & 8 & 2 & - & $\begin{array}{c}0,29 \\
(0,01-4,20)\end{array}$ & - & $\begin{array}{c}0,29 \\
(0,01-4,20)\end{array}$ \\
\hline
\end{tabular}

$\mathrm{CL} \pm \mathrm{P}=$ cleft lip with or without cleft palate; $\mathrm{CPO}=$ cleft palate only; $[(\mathrm{CL} \pm \mathrm{P})+\mathrm{CPO}]=$ all cases of nonsyndromic orofacial clefts; $\mathrm{n}$, excludes indeterminate responses; $\mathrm{a}=$ adjusted for schooling, maternal age, presence of factories in the vicinity, and residence in agricultural area; $b=$ teachers, educators, sociologists, recreational workers, bank employees; $c=$ packagers, workers in the electric industry.

\section{Discussion}

The present study was designed to analyze potentially harmful exposures for fetal development, particularly through risk measures associating such exposures with orofacial clefts. Household exposure to insecticide use combined with pesticide spraying by Ministry of Health vector control agents showed increased risk both for the pre-gestational period and first trimester of the index pregnancy. The active ingredients most commonly identified among the commercial insecticides were pyrethroids and pyrethrins, with a grade II toxicological classification.

The literature shows evidence of the association between congenital malformations and exposure to common industrial chemical agents such as solvents, pesticides, and metals. ${ }^{5}$ Residential proximity to agricultural/industrial areas was also demonstrated as a risk factor for occurrence of clefts in the current study. As for pesticide exposure, studies in the United States $^{3}$ and Spain 12 showed similar findings, with small risks. In this study conducted in Rio de Janeiro, typical orofacial clefts as a whole were associated with the presence of crop areas (especially 
vegetables, citrus fruits, and legumes) close to the proband's residence during the period prior to the index gestation and during the first trimester. When asked about the use of pesticides in these crop areas, few mothers were able to provide precise information, and the adjusted OR was 1,50.

The main industrial activities described by interviewees were steelmaking, metallurgy, and oil refining (petroleum products industry), which for orofacial malformations as a whole showed a risk of over three times that of non-exposure. The proximity to industrial areas can generate a large number of sources of exposure which are difficult to measure but which could be grouped into organic and inorganic water contaminants, industrial emissions of polyvinyl derivates, pesticides, and solvents. 5 A study combining a series of malformations, including 439 cases of cleft lip/cleft palate, did not identify any exposure associated specifically with this group. 5 The highest risks were associated with the group of inorganic chemical agents.

The occupational analysis described here is based on the report of the type of activity carried out in the previous year and during the first trimester of the index gestation, including information on work load, work sector, products, and equipment/machinery most frequently used. The maternal occupations most heavily associated with the target outcome were the activities grouped under domestic services. Given the diversity of work activities, this group was subdivided into domestic services per se (janitors, domestics, baby-sitters, clothing pressers, etc.), with an OR of 2,89 and beauty services (hairdressers, manicures, etc.) with an OR of 2,00. The same approach was used for professionals and related occupations and production work, in which no sub-group was statistically associated with the outcomes $[(\mathrm{CL} \pm \mathrm{P})$ $+\mathrm{CPO}]$.

Occupational exposure to solvents has been the target of various studies, and solvents are usually identified as a potential risk factor for a series of malformations.6,13-16 Beginning in the latter half of the 20th century, there has been widespread use of solvents in various types of human activity. One of the most common families of solvents is that of glycol ether, with approximately 40 chemical substances derived from ethylene glycol and propylene glycol, which are highly soluble in water and numerous organic fluids. 5

Comparing a group of 388 mothers of patients with cleft lip/cleft palate and their controls, occupational exposure to solvents was more frequent among cases, particularly in occupations such as painters, industrial janitors, and typographers, among others. Aromatic and aliphatic hydrocarbons were equally associated with increased risk. ${ }^{13}$ In this study, evaluation of the association between maternal occupational exposure and various malformations, including orofacial clefts, resulted in a crude OR of 7,9 for highly frequent exposure to solvents, and the most frequently cited occupational group was that of janitors. Simultaneously, this occupational group presents the lowest socioeconomic level, highest risk of low birthweight gestations, and other elements associated with reproductive problems, the effects of which on congenital malformations may hinder the measurement of the attributable risk of other potential teratogens. In addition, some other authors have identified a reduction in sperm count among workers exposed to groups of solvents, associating them with toxic effects on the human reproductive system.6,16

Another study identifies additional occupations potentially associated with orofacial clefts, including dry-cleaning workers, hairdressers, and leather manufacturing workers. 15 Various stages of leather manufacturing involve exposure particularly to aliphatic and chlorinated hydrocarbons, in addition to other solvents with different levels of intensity, degree, and duration.

The glycol ether group is widely identified in products for industrial and domestic use, such as paints, varnishes, cosmetics, cleaning agents (especially for glass), and products used in mechanics and metallurgy. In the present study, all mothers belonging to the domestic services group reported daily use of various household cleaning products whose most commonly described active ingredients were ortho-benzyl-para-chlorophenol, alkyl-dimethyl-benzyl-amine chloride, ethylene glycol, and other classes of solvents.

Another occupational group sometimes associated with increased risk of orofacial clefts is that of health care workers. In the present study, this group showed an almost double risk for these malformations as a whole. The risk may be specifically high for nurses, nursing technicians, and laboratory technicians. Some studies based on questionnaires have identified an increased risk of various groups of malformations among women working in health care, especially those with the greatest contact with anesthetic gases, as well as cytotoxic drugs, although the putative mechanism is not conclusive. 10,15 Besides, more than $75 \%$ of the work load was spent in activities in which the woman had to stand, especially in sales and health care, ${ }^{4}$ showing other adverse effects of maternal working conditions during the peri-conceptional period. The underlying mechanism in this as- 
sociation is still obscure, suggesting that the physiological response to extenuating work loads might be represented by hormonal alterations involving catecholamine levels, reduced blood supply and increased uterine irritation, reduced placental function, and inhibition of fetal movement, culminating by jeopardizing the nutritional sources related to fetal growth. Stressful situations have been reported in the literature as potential risk factors for the occurrence of orofacial clefts, as in Chile, where an increase was recorded in the number of cases after a major earthquake, 17 in addition to another study associating increased occurrence of $\mathrm{CL} \pm \mathrm{P}$ and $\mathrm{CPO}$ with episodes classified as stressful. 18 In addition to the mechanism described as involving catecholamines in biological responses to stressful situations, it has been suggested that in the face of such situations (loss of job, death of family members, separation from spouse, etc.) the body synthesizes high concentrations of corticosteroids, already described as teratogens in animal models 19 and associated with orofacial clefts according to some epidemiological studies. ${ }^{7}$

The data analyzed did not identify any paternal exposure with a potential adverse effect on the index gestational outcome, a result similar to that of other studies. 12,20 However, this observation should be interpreted with caution, since the surrogate source of information was maternal, and some authors question the validity of information on paternal occupational exposures as reported by mothers. 3 This opinion had already been expressed in another study according to which the characteristics of occupational history reported by mothers and fathers is discordant. ${ }^{21}$ Surrogate paternal informants furnish data of questionable quality, especially when the father has held various jobs during the period in question, when the recall period is long, or even when very specific exposure information is necessary.

Since mothers of malformed children apparently recall exposures during pregnancy more accurately than healthy control's mothers, recall bias has been a cause for concern in any restrospective study of risk factors for congenital anomalies. ${ }^{22,23}$ In an attempt to avoid this bias, some studies have used infants with anomalies other than that being studied (malformed controls) instead of using unaffected (healthy) controls. The use of malformed controls, however, has also been questionned because it implies that the specificity of the association - and not the association itself - is being examined. Although we can not rule out the occurrence of a recall bias, it seems very unlikely in the current study or insignificant because affected infants (cases of nonsyndromic oral clefts) were compared to non-malformed sick controls admitted to the hospital, besides the effect of questionnaire design used. 24

In light of the results obtained here, it is important to note the potential effect of prolonged use of household insecticides as well as some activities in which a wide range of solvents are routinely applied. Some limitations to this type of exploratory investigation can be identified, like the small number of observations in each stratum, which sometimes hinders the construction or risk measures or generates estimates with wide confidence intervals. One cannot fail to mention the possible effect of a selection bias in the construction of measures, admitting that health care professionals might have better access to a specialized referral. Another possible bias relates to the evaluation of sources of contaminants like insecticides and pesticides, especially those contained in foodstuffs, which were not evaluated. Despite these caveats, some of the findings corroborate the prevailing literature, suggesting the phenomenon's reproducibility. Investigations should be conducted that are specifically designed to elucidate new clues, like the association between this group of malformations and the use of household insecticides, in addition to certain occupational exposures, for example, in the health care sector.

\section{Aknowledgments}

The authors are grateful to Drs. Samuel Warth (director), Sérgio Zanini, coordinator of Centro de Tratamento de Fissuras Lábio-palatais (CEFIL), Cynthia M de Biasi Britto and Maria C. Rendeiro (Phoniatrics section), and Maria de Fátima Brandão (Odontology section) as well as to the remaining staff of Nossa Senhora do Loreto Municipal Hospital, Rio de Janeiro, for their invaluable support during the data collecting phase of this study, besides the financial resources from Fundação Oswaldo Cruz (FIOCRUZ) and Conselho Nacional de Desenvolvimento Científico e Tecnológico (CNPq) (142027/00$6)$. 


\section{References}

1. Erickson JD, Cochran WM, Anderson CE. Parental occupation and birth defects. Contrib Epidemiol Biostat 1979; 1:107-17 apud Bianchi F, Cianciulli D, Pierini A, Constantini AS. Congenital malformations and maternal occupation: a registry based case-control study. Occup Environ Med 1997; 54: 223-8.

2. Kürppa K, Holmberg P, Hernberg S, Rantala K, Riala R, Nurminen T. Screening for occupational exposures and congenital malformations: preliminary results from a nationwide case-control study. Scand J Work Environ Health 1983; 9: 89-93.

3. Shaw G, Gold EB. Methodological considerations in the study of parental occupational exposures and congenital malformations in offspring. Scand J Work Environ Health 1988; 14: 344-55.

4. Lin S, Gensburg L, Marshall EG, Roth GB, Dlugosz L. Effects of maternal work activity during pregnancy on infant malformations. J Occup Environ Med 1998; 40: 829-34.

5. Croen LA, Shaw GM, Sanbonmatsu L, Selvin S, Buffler PA. Maternal residential proximity to hazardous waste sites and risk for selected congenital malformations. Epidemiology 1997; 8: 347-54.

6. Cordier S, Bergeret A, Goujard JHA, Ha MC, Aymé S, Bianchi F, Calzolari E, De Walle HEK, Kill-Jones R, Candela S, Dale I, Dananché B, Vigan C, Fevotte J, Kiel $\mathrm{G}$, Mandereau L, Congenital malformations and maternal occupational exposure to glycol ethers. Epidemiology $1997 ; 8$ : 355-62.

7. Leite ICG, Paumgartten FJR, Koifman S, Exposição a agentes químicos na gravidez e fendas lábio-palatinas no recém-nascido. Cad Saúde Pública 2002; 18: 17-31.

8. Leite ICG. Estudo da associação entre exposições ambientais e ocupacionais e a ocorrência de fendas lábio-palatinas em uma amostra hospitalar [tese doutorado]. Rio de Janeiro: Escola Nacional de Saúde Pública da Fundação Oswaldo Cruz (FIOCRUZ); 2002.

9. Boffetta P, Brennann P, Hererro R. Occupational questionnaire research protocol: viruses, environment and cancer of the oral cavity and the larynx in Mercosul Countries. Lyon: International Agency of Research on Cancer, WHO; 1998.

10. International Labor Office. International standard classification of occupations. Geneva: The Labor Office; 1968 apud Lorente C, Cordier S, Bergeret A, De Valle HEK, Goujard J, Aymé S, Knill-Jones R, Calzolari E, Bianchi F. Maternal occupational risk factors for oral clefts. Scand J Work Environ Health 2000; 26: 137-45.
11. Lilienfield DE, Stolley PD. Foudations of epidemiology. Oxford: Oxford University Press; 1994. p. 123-5.

12. García AM, Fletcher T, Benavides FG, Orts, E. Parental agricultural work and selected congenital malformations. Am J Epidemiol 1999; 149: 64-74.

13. Holmberg PC, Hernberg S, Kurppa K, Rantala K, Riala, R. Oral clefts and organic solvent exposure during pregnancy. Int Arch Occup Environ Health 1982; 50: 371-6.

14. Laumon B, Martin JL, Bertucat I, Verney MP, Robert E. Exposure to organic solvents during pregnancy and oral clefts: a case-control study. Reprod Toxicol 1996; 10: 15-9.

15. Bianchi F, Cianciulli D, Pierini A, Constantini AS. Congenital malformations and maternal occupation: a registry based case-control study. Occup Environ Med 1997; 54: 223-8.

16. Lorente C, Cordier S, Bergeret A, De Valle HEK, Goujard J, Aymé S, Knill-Jones R, Calzolari E, Bianchi F. Maternal occupational risk factors for oral clefts. Scand J Work Environ Health 2000; 26: 137-45.

17. Montenegro MA, Palomino H, Palomino HM. Influence of earthquake-induced stress on human facial clefting and its simulation in mice. Arch Oral Biol 1995; 40: 33-7.

18. Carmichael SL, Shaw GM. Maternal life event stress and congenital anomalies. Epidemiology 2000; 11: 30-5.

19. Rowland JM, Hendrickx AG. Corticosteroid teratogenicity. Adv Vet Sci Comp Med 1983; 27: 99-128 apud Carmichael SL, Shaw GM. Maternal life event stress and congenital anomalies. Epidemiology 2000; 11: 30-5.

20. Hemminki K, Mutanen KL, Saloniemi I. Congenital malformations by the parental occupation in Finland. Int Arch Occup Environ Health 1980; 46: 93-8.

21. Schnitzer PG, Olshan AF, Savitz DA, Erickson JD. Validity of mother's report of father's occupation in a study of paternal occupation and congenital malformations. Am J Epidemiol 1995; 141: 872-7.

22. Rockenbauer M, Olsen J, Czeizel AE, Pedersen L, Sorensen HT. Euro-Map Group. Recall bias in a case-control surveillance system on the use of medicine during pregnancy. Epidemiology 2001; 12: 461-6.

23. Lieff S, Olshan AF, Werler M, Strauss RP, Smith J, Mitchell A. Maternal cigarette smoking during pregnancy and risk for oral clefts in newborns. Am J Epidemiol 1999; 150: 683-94.

24. Mitchell AA, Cottler LB, Shapiro S. Effect of questionnaire design on recall of drug exposure in pregnancy. Am $\mathrm{J}$ Epidemiol 1986; 123: 670-76.

Recebido em 21 de julho de 2003

Versão final aprovada em 15 de setembro de 2003

Aprovado em 6 de outubro de 2003 